\title{
Enterotoxin-producing bacteria and parasites in stools of Ethiopian children with diarrhoeal disease
}

\author{
T. WADSTRÖM, A. AUST-KETTIS, D. HABTE, J. HOLMGREN, G. MEEUWISSE, \\ R. MÖLLBY, and O. SÖDERLIND \\ From the National Bacteriological Laboratory, Stockholm; Ethio-Swedish Pediatric Clinic, University of Addis \\ Ababa, Ethiopia; Institute of Medical Microbiology, University of Göteborg; and Department of Bacteriology, \\ Karolinska Institutet and National Veterinary Institute, Stockholm, Sweden
}

\begin{abstract}
Wadström, T., Aust-Kettis, A., Habte, D., Holmgren, J., Meeuwisse, G., Möllby, R., and Söderlind, O. (1976). Archives of Disease in Childhood, 51, 865. Enterotoxin-producing bacteria and parasites in stools of Ethiopian children with diarrhoeal disease. Enterotoxinogenic bacteria were isolated from 131 (37\%) of 354 Ethiopian infants and children with acute gastrointestinal symptoms. Only one of these isolates belonged to the classical enteropathogenic serotypes of Esch. coli. Two colonies from each patient were isolated and tested for production of enterotoxin by the rabbit ileal loop test, the rabbit skin test, and an adrenal cell assay. However, only $38 \%$ of the isolated enterotoxinogenic strains were Esch. coli; the others belonged to Klebsiella, Enterobacter, Proteus, Citrobacter, Serratia, and Aeromonas. In 18 patients both isolates were toxinogenic and belonged to different species. The incidence of intestinal parasites was $35 \%$ with no apparent correlation to the occurrence of toxinogenic bacteria in the stools.
\end{abstract}

Diarrhoeal disease of early childhood is common all over the world and the prevalence is less influenced by climate than by other environmental factors (Gordon, 1971). In the developing countries like India and Guatemala high incidences of diarrhoeal disease have been reported with death rates among infants of $17 / 1000$ and in children 1 to 4 years old of $21 / 1000$, which is 519 times the rate in the United States (Gordon, 1971; Mata and Urrutia 1971). Many micro-organisms have been associated with acute diarrhoea but established pathogens can be isolated in only less than half the patients in epidemiological studies both in industrialized and nonindustrialized countries (Freij, 1973; Drachman, 1974).

Vibrio cholerae causes diarrhoea by producing an enterotoxin (Formal, DuPont, and Hornick, 1973). Recent studies have shown that other Gram-negative enteric bacteria can also cause diarrhoea by enterotoxin. Enterotoxinogenic Esch. coli was first found to cause diarrhoea in piglets and calves, but more recently in children and adults as well in India and Vietnam (Gorbach and Khurana, 1972; DuPont

Received 18 February 1976. et al., 1971). However, few epidemiological studies have been made on the relative importance of enterotoxinogenic bacteria compared to conventional pathogens in acute diarrhoeal disease.

Enteritis and intestinal parasitic infection constitute a major health problem in Ethiopian children (Freij, 1973). Among new outpatients of the Ethio-Swedish Pediatric Clinic in 1973, 12\% suffered from enteritis. No established viral, bacterial, or parasitic intestinal pathogen was found in $55 \%$ of the cases, and enteropathogenic Esch. coli serotypes were isolated in only $10 \%$ of the cases (Freij, 1973).

The aim of our study was to assess the relative frequency of enterotoxinogenic bacteria, irrespective of species, among Ethiopian children with diarrhoea or other gastrointestinal complaints. An attempt was also made to determine whether a correlation existed between the coincidence of enterotoxinogenic bacterial strain and intestinal parasites.

\section{Material and methods}

Patients. Stool specimens were randomly sampled from 386 individuals attending the outpatient depart- 
ment of the ESPC and the Kirkos Health Clinic in Addis Ababa, which cater mainly for children of low socioecomomic groups. Specimens were collected from consecutively registered patients, regardless of history of gastrointestinal disease, in an attempt to gather unbiased information. The following criteria were applied before including patients in the study. None was receiving antibiotics or chemotherapy, or was on treatment for any other disease, but parenteral rehydration for up to 3 days before the sampling was acceptable.

The peak incidence of intestinal infections occurs during February-May. Our sampling was done during April-September 1974. There were no epidemics in Addis Ababa at the time, nor was the urban population markedly affected by the drought and famine which struck other parts of Ethiopia at that time.

The 354 patients were grouped according to age and symptoms as follows. Age group (1) 0-12 months, (2) 1-4 years, (3) $>4$ years (Jelliffe, 1966). Symptom groups (I) watery (or) 'cholera-like' diarrhoea, i..e voluminous watery stools dehydrating the patient, often causing great difficulty in recovering faecal material in the liquid masses, (II) diarrhoea with blood and/or mucus (or 'dysentery-like') with more than 4 stools over 24 hours. The diarrhoeal stools were loose, foul smelling, and contained macroscopical blood and/or mucus. (III) Gastrointestinal symptoms with no diarrhoea but more than one of the following symptoms: nausea, vomiting, colicky pains, flatulence, and abdominal distension. A fourth group comprised only 17 children without any gastrointestinal complaints and with normal stool findings. This group, however, was not considered representative as a control group, and was not included in this report. In addition, samples were taken from 15 healthy student nurses at the clinics.

Bacteriological methods. Stool specimens were inoculated in the Stuart transport medium (Kallings, 1968) and flown to Stockholm within 10 days without any special cooling precautions. Isolation and primary identification were carried out according to Edwards and Ewing (1972). Each stool specimen was plated on horse-blood, deoxycholate citrate (DC), and Endo and thiosulphate-citrate-bilesalts sucrose (TCBS) agar plates. Kauffman tubes were inoculated and incubated overnight before the organisms were plated on additional DC and Endo agar plates. Two colonies with different morphology on Endo agar plates were subcultured on Endo agar and stored on deep agar tubes at $20^{\circ} \mathrm{C}$ for subsequent biochemical tests and serological typing. All strains thus isolated were inoculated in brain heart infusion broth (BHI, Difco) in tubes containing $10 \mathrm{ml}$ of liquid medium. The tubes were incubated on a shaker $\left(200 \mathrm{rpm}, 16 \mathrm{~h}, 37^{\circ}\right)$ and centrifuged $(4000 \times g \times$ $20 \mathrm{~min}, 4^{\circ}$ ). Supernatants were then tested for enterotoxin activity.

Biochemical typing was performed with the API system (Analytab, New York, N.Y.) as recently described (Nord, Wadström, and Dahlbäck, 1976). Each toxinogenic isolate was also identified in a second laboratory independently, using the methods of Edwards and Ewing (1972). Each isolate of Esch. coli was agglutinated with a polyvalent serum for enteropathogenic serotypes of Esch coli; Salmonella and Shigella were identified with standard methods using antisera prepared at the National Bacteriological Laboratory. O-serogrouping of enterotoxinogenic strains was done by Drs. Ida and Frits Ørskov at the WHO Escherichia Reference Centre, Copenhagen.

Tests for enterotoxin. Enterotoxin activity was tested by three methods: (1) rabbit intestinal loop test, (2) rabbit skin test, and (3) adrenal cell test. Undiluted $1 \mathrm{ml}$ culture supernatants were injected in jejunal loops in young adult New Zealand rabbits starting approximately $50 \mathrm{~cm}$ from the pylorus (25 loops per rabbit) (Holmgren, Söderlind, and Wadström, 1973). The skin test was performed as recently described with 0.1 ml undiluted samples (Pierce and Wallace, 1972). The adrenal cell assay was performed twice in 1/10 dilution of each specimen (Donta et al., 1974). All three tests were performed in duplicate by the same person unaware of the history of the patient.

Strains classified as toxinogenic fulfilled the following criteria. (1) The results of the adrenal cell test were positive twice. (2) They gave positive rabbit intestinal loop tests and/or rabbit skin tests. All assays were performed on supernatants stored undiluted at $-20^{\circ}$ for less than one week after cultivation.

Parasitological methods. All stool specimens obtained were examined fresh for ova and protozoa and again after formolether concentration according to Ridley and Hawgood (1956).

\section{Results}

Table I shows the distribution of 354 patients in the age and symptoms groups. The youngest age group was predominate in symptom group I with watery diarrhoea, while in group II children 1 to 4 years of age predominated. This group contained $38 \%$ (135) of the patients.

\section{TABLE I}

Distribution of the 354 Ethiopian outpatients, grouped according to age and symptoms

\begin{tabular}{l|c|c|c|c}
\hline \multirow{2}{*}{ Age groups } & \multicolumn{2}{|c|}{ Symptom groups } & \multirow{2}{*}{ Total } \\
\cline { 2 - 3 } & I & II & III & \\
\hline (1) $0-12 \mathrm{~m}$ & $\mathrm{n}(\%)$ & $\mathrm{n}(\%)$ & \\
\hline$(2) 1-4 \mathrm{yr}$ & $47(13)$ & $61(17)$ & 0 & $108(31)$ \\
$(3)>4 \mathrm{yr}$ & $17(5)$ & $135(38)$ & $7(2)$ & $159(45)$ \\
\hline Total & 0 & $49(14)$ & $38(11)$ & $87(25)$ \\
\hline
\end{tabular}

^I, watery diarrhoea; II, bloody and/or mucus diarrhoea; III, gastrointestinal symptoms; no diarrhoea. 
Two bacterial isolates from each stool culture were assayed in the rabbit intestinal loop test, rabbit skin test, and the adrenal cell test before the species of each strain was diagnosed by biochemical tests. The frequency of enterotoxinogenic $\left(\mathrm{ent}^{+}\right.$) strains in the different age and symptom groups is listed in Table II. A remarkable finding was the high

TABLE II

Distribution of patients with enterotoxinogenic bacterial isolates by age and symptom groups

\begin{tabular}{l|c|c|c|c}
\hline \multirow{2}{*}{ Age groupst } & \multicolumn{3}{|c|}{ Symptomst } & \multirow{2}{*}{ Total } \\
\cline { 2 - 4 } & $\begin{array}{c}\text { I } \\
\text { n (\%) }\end{array}$ & $\begin{array}{c}\text { II } \\
(\mathrm{n} \%)\end{array}$ & $\begin{array}{c}\text { III } \\
\text { n (\%) }\end{array}$ & \\
\hline 1 & $19(40) \star$ & $21(34)$ & - & $40(37)$ \\
3 & $5(29)$ & $49(36)$ & $2(29)$ & $56(35)$ \\
\hline & - & $22(45)$ & $13(34)$ & $35(40)$ \\
\hline & $24(38)$ & $92(38)$ & $15(33)$ & $131(37)$ \\
\hline
\end{tabular}

* Number of patients with enterotoxinogenic strains and in parentheses the percentage of the total number of patients in the respective group (according to Table I).

tSee Table I.

incidence of ent ${ }^{+}$strains in all groups, $37 \%$ (131), with no significant difference between the age and symptom groups. The stools of 4 of the 15 student nurses also contained ent ${ }^{+}$strains, which might be explained by close contact with children with ent $^{+}$diarrhoea.

Biochemical testing in two different laboratories with a conventional biochemical test and with a commercial kit (API) gave the same diagnosis of species in all but three of the 710 strains from the 369 individuals. An interesting finding was the relatively high frequency of ent ${ }^{+}$enteric bacteria other than Esch. coli (Table III). Only 11 strains of Salmonella and 8 of Shigella were found in the whole material, all of them nontoxinogenic. In 18

\section{TABLE III}

Species of enterotoxinogenic bacterial strains isolated

\begin{tabular}{l|c|c}
\hline \multicolumn{1}{c|}{ Species } & Strains & $\%$ \\
\hline Esch. coli & 66 & 38 \\
Klebsiella & 26 & 15 \\
Enterobacter & 21 & 12 \\
Citrobacter & 19 & 11 \\
Proteus & 12 & 7 \\
Aeromonas & 11 & 6 \\
Serratia & 4 & 2 \\
Pseudomonas & 1 & 1 \\
Not typed & 13 & 8 \\
\hline Total & 173 & 100 \\
\hline
\end{tabular}

$(5 \cdot 1 \%)$ of the patients, where both isolates were ent $^{+}$, the strains belonged to different bacterial species.

In the whole material $24 \%$ ( $173 / 710$ strains) were ent $^{+}$, while $27 \%(66 / 244)$ of all Esch. coli strains isolated were ent ${ }^{+}$. Thus $23 \%(107 / 466)$ of all strains belonging to species other than Esch. coli were found to be enterotoxinogenic. All strains of Esch. coli were O-grouped, and only one single ent $^{+}$strain was found to belong to the classical enteropathogenic serotypes; of the ent- strains of Esch. coli (178 strains) only 6 strains were of enteropathogenic serotypes. They were equally distributed over the different symptom and age groups.

Recovery of parasites. The results of the parasitological stool examination in the three different symptom groups are summarized in Tables IV and V. In group I with watery, 'cholera-like' diarrhoea the incidence of parasites was low. This

\section{TABLE IV}

Distribution of patients with parasites in their stools by age and symptom groups

\begin{tabular}{l|c|c|c|c}
\hline \multirow{2}{*}{ Age groups } & \multicolumn{4}{c|}{ Symptoms } \\
\cline { 2 - 4 } & I & II & III & Total \\
\hline 1 & $\mathrm{n}(\%)$ & $\mathrm{n}(\%)$ & $\mathrm{n}(\%)$ & \\
\hline 2 & $2(4) \star$ & $8(13)$ & - & $10(9)$ \\
3 & $1(6)$ & $63(47)$ & $1(14)$ & $65(41)$ \\
\hline Total & - & $26(53)$ & $22(58)$ & $48(55)$ \\
\hline
\end{tabular}

*Number of patients with parasites and in parentheses the percentage of the total number of patients (354) in the respective group (according to Table I).

\section{TABLE V}

Distribution of patients with parasites and enterotoxinogenic bacterial isolates by age and symptom groups

\begin{tabular}{l|c|c|c|c}
\hline \multirow{2}{*}{ Age groups } & \multicolumn{3}{|c|}{ Symptoms } \\
\cline { 2 - 5 } & I & II & III & Total \\
\hline 1 & $\mathrm{n}(\%)$ & $\mathrm{n}(\%)$ & $\mathrm{n}(\%)$ & \\
\hline 3 & $1(5)^{\star}$ & $3(14)$ & - & $4(10)$ \\
& $1(20)$ & $22(45)$ & $1(50)$ & $24(43)$ \\
\hline Total & - & $10(45)$ & $6(46)$ & $16(46)$ \\
\hline
\end{tabular}

*Number of patients with parasites among those with enterotoxinogenic bacterial isolates in the respective group (according to Table II); percentage in parentheses. 
could be due not only to the difficulty in finding faecal material in the voluminous liquid masses, but also to the fact that these patients were predominantly younger than one year, at which time there is normally a lower rate of infestation. It is obvious from Tables IV and V that there was no correlation between the incidence of parasites and ent ${ }^{+}$strains.

\section{Discussion}

Most of the children (45\%) with diarrhoeal disease belonged to the age group 1 to 4 years (group 2, Tables 1 and II), which agrees with previous studies from developing countries (Gordon, 1971; Mata and Urrutia, 1971; Drachman, 1974). The children came mainly from low socioeconomic groups, and many case histories could be correlated with poor sanitation. Those with cholera-like disease (group I, Table I) had an acute onset and were usually in bad condition. The children with dysentery-like disease (group II, Table I) were on average older.

The parasitological findings agree with those in a study from Botswana (Cooper and Johnson, 1973) but contrary to that study we, and Freij (1973), found only a few enteropathogenic Esch. coli strains. Shigella and Salmonella were also isolated only from a few cases. This may in part be due to the long transport.

It is of interest that the incidence of the enterotoxinogenic strains was similar in the different age and symptom groups, i.e. no predominance of such strains was noted in the cases with watery, cholera-like diarrhoea. Together with reports from other geographical areas the present findings suggest a world-wide high incidence of enterotoxinogenic bacteria in diarrhoea of children as well as adults (Gordon, 1971; Drachman, 1974; Formal et al., 1973; Gorbach and Khurana, 1972).

An altered distribution of Esch. coli in the mouse intestinal tract was recently noted after oral infection with a metazoan pathogen (Cypess et al., 1974). Since disease with enterotoxinogenic and enteropathogenic Esch coli is dependent on colonization of the upper small intestine both in animals and children (Challacombe et al., 1974; Heyworth and Brown, 1975) this suggests that parasitic infections may play a role in the pathogenesis of bacterial infantile diarrhoea (Freij, 1973; Drachman, 1974). We did not, however, find any correlation between the incidence of parasites in faecal and enterotoxinogenic stool isolates.

The most common parasite isolated in our study was Ascaris (12\%), followed by Entamoeba histolytica (9\%). Giardia lamblia was recovered in $5 \%$. A greater number of parasites was diagnosed with increasing age, and an overall incidence of E. histolytica (10-12\%) was found to agree with a previous study from the same clinic (Freij, 1973). A high incidence of ova was found in all age groups without any apparent correlation with the clinical symptoms.

A recent study on travellers' diarrhoea in Mexico (Gorbach et al., 1975) showed a high incidence of toxinogenic isolates $(68 \%)$. In a study from a nursery in Brazil 85\% harboured enterotoxinogenic strains in their stools during the period of acute diarrhoea (Guerrant et al., 1975). In a search for enterotoxinogenic Esch. coli in 59 Apache Indian children only $16 \%$ of the episodes of diarrhoea were found to be caused by such organisms (Sack et al., 1975). However, since biochemical identification of species and serotyping of Esch. coli probably preceded the bioassays in these studies, the incidence of enterotoxinogenic enteropathies (Formal et al., 1973) might have been higher when compared to this study.

The overall high incidence of enterotoxinogenic strains of Esch. coli and other Gram-negative enteric organisms such as Klebsiella, Enterobacter, Proteus, Citrobacter, and Yersinia sp. (Acres et al., 1975; Koupal and Deibel, 1975) and also of Aeromonas and Pseudomonas, which are taxonomically related to $V$. cholerae (Staley and Colwell, 1973), is an interesting epidemiological finding. Klipstein et al. (1973) recently reported on toxinogenic Klebsiella and Enterobacter isolated from jejunal aspirates of patients with tropical sprue. In a recent study on acute diarrhoea in calves an isolate of Citrobacter gave a positive intestinal loop test (Acres et al., 1975). It is thus possible that either a whole family of enterotoxins may exist in different Gram-negative species, even in such pathogens as certain Salmonella and Shigella sp., or that plasmids controlling enterotoxin production can spread between related species as can antibiotic resistance factors (Gyles, So, and Falkow, 1974; Lacey, 1975).

The high incidence of toxinogenic strains of species other than Esch. coli (Table III), previously unreported, might be explained by the fact that in our study colonies were tested for enterotoxicity before the final biochemical typing to species level. Plasmid control of production, at least of Esch. coli enterotoxin (Gyles et al., 1974), and the fact that there is no correlation of toxin production with the classical enteropathogenic serotypes as described by Gorbach and Khurana (1972) were confirmed in this study. This shows the importance of bioassays for diagnostic and epidemiological studies of acute diarrhoeal disease in children, adults, and animals. The high incidence of enterotoxinogenic isolates 
reported in this study (Table II) is a minimum value since overgrowth of certain strains and suppression of others in the Stuart transport medium cannot be excluded.

The rabbit intestinal loop assay is the classical test both for cholera and Esch. coli enterotoxin. However, this is probably not sensitive enough for detection of toxin in broth cultures for all enterotoxinogenic strains (Gorbach and Khurana, 1972: Klipstein et al., 1973). A tissue culture system for toxin detection is 100 times more sensitive and is simpler to use when a large number of strains are investigated as in this study.

The adrenal cell model and tissue culture systems like Chinese hamster ovary cells (Guerrant et al., 1975) measure the heat labile toxin, and since strains might exist which only produce heat-stable toxin (Gorbach, 1974), the intestinal loop assay which detects both types of toxin should probably not be excluded from further epidemiological studies. This comparative study confirmed that the cell test was more sensitive, simpler to perform, and less time-consuming than the others.

Some strains were difficult to assay in all three test systems, since they produce other toxins such as haemolysin and probably other cytotoxins as well. There were test samples that gave dermonecrosis in the skin test instead of the typical blueing of cholera and Esch. coli enterotoxin. Some of these strains might have been enterotoxinogenic but had to be excluded since they did not fulfill the criteria of this study. However, comparisons with each strain in different laboratories gave good agreement among the three tests. The skin test was more difficult to read and interpret than the other two, however.

Epidemiological studies on diarrhoeal disorders in different geographical areas will extend our knowledge of this global health problem. Together with various toxinogenic enterobacteria, viruses such as rotavirus may account for most of the undiagnosed cases of acute diarrhoea (Davidson et al., 1975). Furthermore, Esch. coli, and perhaps related species also, is known to cause diarrhoeal disease by invading the intestinal mucosa without producing an enterotoxin (Formal et al., 1973; DuPont et al., 1971). When suitable laboratory methods have been developed for detecting such invasive strains as well, the days when no aetiological agent could be found in most patients with acute diarrhoea will be past.

The help and support of Dr. Mehari Gebre Medhin, ENI, and Ass. prof. Göran Kronvall, AHRI in Addis Ababa during this study are gratefully acknowledged. Bioassays on the bacterial isolates used and interpreta- tion of results from four different laboratories were carried out with the skilful technical assistance of Ms S.-B. Karlsson, M. Kjellgren, K. Jäderberg, C. Lönnroth, G. Sigstam, and Mr. P. Allestam.

We are grateful to Drs. Bradley Sack and David Sack for the first culture of adrenal Y 1 cells and for advice on cultivation of these cells and testing of enterotoxins.

One of us (A. A-K.) was employed by SIDA during April-August 1974 as a research assistant at the ESPC. G. M. had a fellowship from the Swedish Medical Research Council (19P-4314). J. H. and R. M. have positions at the Council. The investigation was partly supported by a grant from the Swedish Council for Agriculture and Forestry Research. Part of this study was presented at a meeting on enterotoxins in Kusize, Czechoslovakia, September 1975.

\section{REFERENCES}

Acres, D. S., Laing, C. J., Saunders, J. R., and Radostits, O. M. (1975). Acute undifferentiated neonatal diarrhoea in beef calves. I. Occurrence and distribution of infectious agents. Canadian fournal of Comparative Medicine and Veterinary Science, 39, 116.

Challacombe, D. N., Richardson, J. N., Rowe, B., and Anderson, C. M. (1974). Bacterial microflora of the upper gastrointestinal tract in infants with protracted diarrhoea. Archives of Disease in Childhood, 49, 270.

Cooper, A. C. D., and Johnson, R. H. (1973). The bacteria and parasites found in Batswana children with acute gastroenteritis. South African Medical fournal, 47, 1705.

Cypess, R. H., Swidwa, D. W., Kenny, J. S., and Yee, R. B. (1974). Influence of Metazoan infection in the mouse on enteric colonization and immune response to Escherichia coli. Fournal of Infectious Diseases, 130, 534.

Davidson, G. P., Bishop, R. F., Townley, R. R. W., Holmes, I. H., and Ruck, B. J. (1975). Importance of a new virus in acute sporadic enteritis in children. Lancet, 1, 242.

Donta, S. T., Sack, D. A., Wallace, R. B., Dupont, H. L., and Sack, R. B. (1974). Tissue-culture assay of antibodies to heat-labile Escherichia coli enterotoxins. New England fournal of Medicine, 291, 117.

Drachman, R. J. (1974). Acute infectious gastroenteritis. Pediatric Clinics of North America, 21, 711.

Dupont, H. L., Formal, S. B., Hornick, R. B., Snyder, M. J., Libonati, J. P., Sheahan, D. G., LeBrec, E. H., and Kalas, J. P. (1971). Pathogenesis of Escherichia coli diarrhoea. New England fournal of Medicine, 285, 1.

Echeverria, P., Blacklow, N. R., and Smith, D. H. (1975). Role of heat-labile toxigenic Escherichia coli and reovirus-like agent in diarrhoea in Boston children. Lancet, $2,1113$.

Edwards, P. R., and Ewing, W. H. (1972). Identification of Enterobacteriaceae, 3rd ed. Burgess, Minneapolis.

Formal, S. D., Dupont, H. L., and Hornick, R. B. (1973). Enterotoxic diarrheal syndromes. Annual Review of Medicine, 24, 103.

Freii, L. (1973). Observations on parasitic and bacterial infections of the intestine among paediatric outpatients in Addis Ababa. Ethiopian Medical fournal, 11, 13.

Gorbach, S. L. (1974). Scatologic aspect of Escherichia coli. Lancet, 1, 50.

Gorbach, S. L., and Khurana, C. N. (1972). Toxinogenic Escherichia coli. A cause of infantile diarrhea in Chicago. New England Fournal of Medicine, 287, 791.

Gorbach, S. L., Kean, B. H., Evans, D. G., Evans, D. J., and Bessudo, D. (1975). Travellers' diarrhea and toxinogenic Escherichia coli. New England fournal of Medicine, 292, 933.

Gordon, J. E. (1971). Diarrheal disease of early childhood: world wide scope of the problem. Annals of the New York Academy of Sciences, 176, 9.

Guerrant, R. L., Moore, R. A., Kirschfeld, P. M., and Sande, M A. (1975). Role of toxinogenic and invasive bacteria in acute diarrhoea of childhood. New England fournal of Medicine, 293, 567. 
Gyles, C. S. M., So, M., and Falkow, S. (1974). The enterotoxin plasmids of Escherichia coli. Fournal of Infectious Diseases, 130, 40.

Heyworth, B., and Brown, J. (1975). Jejunal microflora in malnourished Gambian children. Archives of Disease in Childhood, 50, 27.

Holmgren, J., Söderlind, O., and Wadström, T. (1973). Crossreactivity between heat-labile enterotoxins from Vibrio cholerae and Escherichia coli in neutralization tests in rabbit ileum and skin. Acta Pathologica et Microbiologica Scandinavica, B81, 757.

Jelliffe, D. B. (1966). The Assessment of the Nutritional Status of the Community. Monograph Series No. 53. World Health Organization, Geneva.

Kallings, L.-O. (1968). Transport of bacterial specimen. Biotechnology and Bioengineering, 10, 399.

Klipstein, F. A., Holdeman, L. W., Corcino, J. J., and Moore, W. E. C. (1973). Enterotoxigenic bacteria in tropical sprue. Annals of Internal Medicine, 79, 632.

Koupal, L. R., and Deibel, R. H. (1975). Assay, characterization and localization of an enterotoxin produced by salmonella. Infection and Immunity, 11, 14.

Lacey, R. W. (1975). A critical appraisal of the importance of $\mathrm{R}$-factors in the enterobacteriaceae in vivo. Fournal of Antimicrobial Chemotherapy, 1, 25.

Mata, L. J., and Urrutia, J. J. (1971). Intestinal colonization of breast-fed children in a rural area of low socioeconomic level. Annals of the New York Academy of Sciences, 176, 93.

Nalin, D. R., McLaughlin, J. C., Rahaman, M., Yunus, M., and Curlin, G. (1975). Enterotoxigenic Escherichia coli and idiopathic diarrhoea in Bangladesh. Lancet, 2, 1116.

Nord, C. -E., Wadström, T., and Dahlbăck, A. (1975). Evaluation of different diagnostic kits for enterobacteriaceae. New Approaches to Identification of Micro-organisms, p. 393 . Ed. by L. G. Hedén and T. Illéni. Wiley, New York.

Pierce, N. F., and Wallace, C. K. (1972). Stimulation of jejunal secretion by a crude Escherichia coli enterotoxin. Gastroenterology, 63, 439.

Ridley, D. S., and Hawgood, B. C. (1956). The value of formolether concentration of faecal cysts and ova. Fournal of Clinical Pathology, 8, 74.

Rudoy, R. C. and Nelson, J. D. (1975). Enteroinvasive and enterotoxinogenic Escherichia coli. Occurrence in acute diarrhea of infants and children. American fournal of Diseases of Children, $129,668$.

Sack, R. B. (1975). Human diarrheal disease caused by entero- toxigenic Escherichia coli. Annual Review of Microbiology, 29, 333.

Sack, R. B., Hirschhorn, N., Brownlee, I., Cash, R. A., Woodward, W. E., and Sack, D. A. (1975). Enterotoxigenic Escherichia coli-associated diarrheal disease in Apache children. New England Fournal of Medicine, 292, 1041.

Staley, T. E., and Colwell, R. R. (1973). Deoxyribonucleic acid reassociation among members of the genus Vibrio. International fournal of Systemic Bacteriology, 23, 316.

Correspondence to Dr. T. Wadström, National Bacteriological Laboratoty, S-105 21 Stockholm, Sweden.

\section{Addendum}

Since this paper was completed several studies on the epidemiology of enterotoxinogenic bacteria in infantile diarrhoea in different geographic areas have been published. Guerrant et al. (1975) in a hospital in Brazil found 20 instances (50\%) of enterotoxinogenic Esch. coli, Klebsiella, and Enterobacter sp. in a group of 40 children with diarrhoea. In a hospital in Texas (Rudoy and Nelson, 1975) enterotoxin-producing Esch. coli were found in 36 children ( $86 \%$ of the total) with diarrhoeal disease, but also in $41 \%$ of a control group of 17 children, while isolates which produced enterotoxin and were invasive were only found among the children with acute intestinal symptoms. A study of 493 children in Bangladesh with diarrhoea showed that $55 \%$ harboured enterotoxinogenic bacteria (Nalin et al., 1975), while in Boston (Echeverria, Blacklow, and Smith, 1975), no enterotoxin-producing bacteria but rotaviruses were reported in 61 of 61 children. These recent observations clearly indicate the need for further work on the epidemiology of acute diarrhoeal disease, and show the impact of enterotoxinogenic bacteria in different geographical areas among different socioeconomic groups (Sack, 1975). 